УдК $347.73 ; 336.2$

\author{
Є. О. Яковенко
}

\title{
ДЕЯКІ ПРАВОВІ АСПЕКТИ ДОСУДОВОГО ЗАХИСТУ КОНСТИТУЦЙНИХ ПРАВ ЛЮДИНИ І ГРОМАДЯНИНА УПОВНОВАЖЕНИМ ВЕРХОВНОЇ РАДИ УКРАЇНИ 3 ПРАВ ЛЮДИНИ
}

Постановка проблеми. Інститут Упововаженого Верховної Ради України з прав людини в новітній історії України здобув свій початок 28 червня 1996 року з моменту прийняття Конституції України.

Так, відповідно до статті 101 Конституції України парламентський контроль за додержанням конституційних прав і свобод людини і громадянина здійснює Упововажений Верховної Ради України з прав людини (далі Уповноважений), а у частині третій статті 55 вказано, що кожен має право звертатися за захистом своїх прав до Упововаженого [1].

Пряма дія норм Конституції України означає, що ці норми застосовуються безпосередньо; законами України та іншими нормативно-правовими актами можна лише розвивати конституційні норми [2].

Мета - розглянути правові аспекти досудового захисту конституційних прав і свобод людини і громадянина під час звернення до Уповноваженого Верховної Ради з прав людини, зокрема його компетенції та порядок розгляду звернень, одержання доказів.

Виклад основного матеріалу. Розвиток вищезазначені норми Конституції України отримали в Законі України № 776/97-ВР «Про Уповноваженого Верховної Ради України з прав людини», який був прийнятий Верховною Радою України 23.12.1997 та набрав чинності 15.01.1998 року (далі - Закон № 776/97). Положеннями Закону № 776/97 в тому числі врегульовано правовий статус, компетенція, порядок розгляду Уповноваженим звернень громадян [3].

Зокрема, визначено, що Уповноважений у своїй діяльності керується Конституцією України, законами України, чинними міжнародними договорами, згода на обов'язковість яких надана Верховною Радою України. Він зобов'язаний забезпечувати виконання покладених на нього функцій та повною мірою використовувати надані йому права [3]. 
Уповноважений здійснює свою діяльність незалежно від інших державних органів та посадових осіб. Діяльність Уповноваженого доповнює наявні засоби захисту конституційних прав і свобод людини і громадянина, не відміняє їх і не тягне перегляду компетенції державних органів, які забезпечують захист і поновлення порушених прав і свобод [3].

Отже, Уповноважений, здійснюючи парламентський контроль за додержанням конституційних прав і свобод людини і громадянина, зобов'язаний забезпечувати виконання покладених на нього функцій та повною мірою використовувати надані йому права, не підміняючи компетенції інших державних органів, які забезпечують захист і поновлення порушених прав і свобод. Зокрема, реалізація Уповноваженим своїх обов'язків (функцій) i повноважень у порядку, що визначений законом у сфері діяльності такого органу, здійснюється ним виключно у спосіб, який передбачений Конституцією України та законами. Вчинення ним дій/прийняття рішень передбачає: наявність суб'єктного складу учасників; врегульованість положеннями закону (процесуальними нормами), чітку регламентацію дій учасників щодо їх вчинення, строків (термінів) їх вчинення чи прийняття рішень за ними; відповідне оформлення результату за вчиненими діями.

Роль Уповноваженого за додержанням конституційних прав і свобод людини і громадянина $є$ важливою в різних сферах діяльності держави, це стосується порушення соціально-економічних прав, а також прав, зокрема, на справедливий суд, пов'язанних із виконанням судових рішень, щодо належних умов тримання в місцях ув'язнення тощо.

Одним із показників ефективністі діяльності Уповноваженого, на думку автора, є фактичне поновлення конституційних прав і свобод людини і громадянина за зверненнями останніх.

На жаль, як показує практика, виникають випадки, коли Уповноважений відноситься формально до виконання покладених на нього функцій та повною мірою не використовує надані йому права. Як приклад цього можливо навести звернення громадянина А. до Уповноваженого за захистом порушеного конституційного права, передбаченого статтєю 40 Конституціііі України, а саме права на одержання обгрунтованої відповіді у встановлений законом строк.

Таке звернення до Уповноваженого грунтувалось на тому, що ПАТ «Укртелеком» не надало відповіді громадянину А. на його три звернення. Крім можливого «листа», відправником якого є (згідно з поштовим конвертом) Дніпропетровська філія ПАТ «Укртелеком», за підписом (як зазначено в листі) представника за довіреністю ПАТ «Укртелеком». При цьому до листа не додано оригіналу чи відповідно завіреної копії довіреності, за якою такий представник має право підпису.

За результатами розгляду звернення громаднина А. представник Уповноваженого прийшов до таких висновків:

1) між громадянином А. та ПАТ «Укртелеком» виникли відносини цивільно-правого характеру, вирішення яких регламентуються положеннями Цивільного кодексу України, Цивільного процесуального кодексу Укра- 
їни, Закону України «Про телекомунікації», Закону України «Про захист прав споживачів». Захист таких прав здійснюється судом;

2) відповідно до частини першої статті 17 Закону України «Про уповноваженого Верховної Ради України з прав людини» Уповноважений приймає та розглядає звернення громадян або осіб, які діють в їхніх інтересах, відповідно до Закону України «Про звернення громадян», статтею 12 якого визначено, що його дія не поширюється на порядок розгляду заяв і скарг громадян, встановлений цивільно-процесуальним законодавством. Таким чином, звернення громадянина А., надіслані до керівництва ПАТ «Укртелеком», не підлягають розгляду в порядку, визначеному Законом України «Про звернення громадян»;

3) лише «за аналізом» змісту звернення громадянина А. дійшов висновку: «лист» є відповіддю ПАТ «Укртелеком» і підписано належною особою (далі - «лист»).

На думку автора, такі правові висновки є передчасними. Законодавство України, яке визначає компетенцію і права Уповноваженого (його представника) та регламентує механізм захисту конституційних прав і свобод людини і громадянина, зокрема під час розгляду і вирішення звернень, має застосовуватись системно та комплексно з урахуванням матеріально-правових і процесуальних норм.

Контроль за дотриманням законодавства про звернення громадян відповідно до своїх повноважень здійснює, зокрема, Уповноважений [4].

Відповідно до статті 17 Закону № 776/97 Уповноважений приймає та розглядає звернення громадян України, іноземців, осіб без громадянства або осіб, які діють в їхніх інтересах, відповідно до Закону України «Про звернення громадян» [3].

Встановлено, що сфера застосування Закону № 393/96 не поширюється на порядок розгляду заяв і скарг громадян [4], встановлений:

- кримінальним процесуальним законодавством;

- цивільно-процесуальним законодавством;

- трудовим законодавством;

- законодавством про захист економічної конкуренції;

- Законом України «Про судоустрій і статус суддів»;

- Законом України «Про доступ до судових рішень»;

- Кодексом адміністративного судочинства України;

- Законом України «Про засади запобігання і протидії корупції»;

- Законом України «Про виконавче провадження».

Щодо звернень вкладників до Фонду гарантування вкладів фізичних осіб щодо виплати Фондом відшкодування в межах гарантованої суми, то вони розглядаються в порядку, встановленому законодавством про систему гарантування вкладів фізичних осіб.

Також не підлягають розгляду та вирішенню такі звернення:

1) без зазначення місця проживання, не підписане автором (авторами), а також таке, з якого неможливо встановити авторство;

2) повторені одним і тим же органом від одного і того ж громадянина з одного і того ж питання, якщо перше вирішено по суті, а також ті звер- 
нення, терміни розгляду яких передбачено статтею 17 Закону № 393/96, та звернення осіб, визнаних судом недієздатними [4].

Відповідно до статті 17 Закону № 776/97 Уповноважений не розглядає тих звернень, які розглядаються судами, зупиняє вже розпочатий розгляд, якщо зацікавлена особа подала позов, заяву або скаргу до суду [3].

Звертаючи увагу на викладене, можливо констатувати, що положеннями Закону № 393/96 та Закону № 776/97 чітко встановлено вичерпний перелік випадків, коли Уповноважений не розглядає звернення громадян України, іноземців, осіб без громадянства або осіб, які діють в їхніх інтересах.

Законом № 393/96 визначено суб’єктний склад, їхні права і обв’язки, механізм ініціювання і початку розгляду та порядок вирішення звернень, оскарження дій чи бездіяльності осіб, яким направлені такі звернення, в разі нездійснення ними відповідних процесуальних дій, які вони зобов'язані вчинити у визначений Законом № 393/96 строк. Відносини з розгляду звернень громадян є основним і єдиним предметом регулювання Закону № 393/96, а тому він є спеціальним у цій сфері.

Таким чином, норми Закону № 393/96 є спеціальними для правовідносин щодо порядку, строків розгляду звернень громадян та мають перевагу під час застосування перед іншими законами, крім Конституції України та чинних міжнародних договорів, згода на обов'язковість яких надана Верховною Радою України. При цьому порядок розгляду заяв і скарг громадян, зокрема щодо мови зверненя, вимог до звернень та строків їх розгляду, Законом № 776/97 не визначається.

Необхідно звернути увагу на те, що відмежування цивільних, адміністративних, трудових та інших правовідносин за участю громадян України від інших правовідносин здійснюється на підставі визначення правової форми їх участі в конкретних правовідносинах.

Реалізація особою права на звернення відповідно до Конституції України і Закону № 393/96 не наділяє особу «автоматично» статусом споживача і не $є$ підставою для поширення на такі правовідносини дії, зокрема положень цивільного і цивільно-процесуального законодавства, Закону України «Про захист прав споживачів». Тобто, зокрема, на правовідносини щодо порядку, строків розгляду заяв і скарг громадян відповідно до Закону № 393/96.

Органи державної влади повинні вчиняти відповідні дії, приймати рішення на підставі та у спосіб, що передбачені Конституцією України та законами України, а також відповідно до порядку, встановленого законом. Це стосується органів як виконавчої, так і судової гілки влади, які повинні діяти відповідно до законів, якими регламентовано механізм (підстава, порядок, процедура) одержання доказів [5].

Правовим наслідком ігнорування цих правил $є$ не тільки очевидна незаконність дій, рішень органів державної влади, зокрема, за якими було одержано відповідні докази, а і їх недопустимість [5].

Відповідно до статті 17 Закону № 776/97 Уповноважений приймає та розглядає звернення громадян України, іноземців, осіб без громадян- 
ства або осіб, які діють в їхніх інтересах, відповідно до Закону України «Про звернення громадян» [3].

Під час розгляду звернення Уповноважений: 1) відкриває провадження у справі про порушення прав $і$ свобод людини $і$ громадянина; 2) роз'яснюе заходи, що їх має вжити особа, яка подала звернення Уповноваженому; 3) направляе звернення за належністю в орган, до компетениії якого належить розгляд справи, та контролюе розгляд цього звернення; 4) відмовляє в розгляді звернення [3].

Таким чином, Законом № $776 / 97$, норми якого є спеціальними щодо порядку розгляду і вирішення Уповноваженим звернень громадян, визначено, що він приймає та розглядає звернення відповідно до Закону № 393 / 96 . При цьому Уповноважений розглядає звернення по суті виключно після відкриття провадження у справі про порушення прав і свобод людини i громадянина. Це надає йому право одержувати від третіх осіб інформацію (відомості) для встановлення обставин, викладених у зверненні. Іншого законом не передбачено.

У той же час представник Уповноваженого в порушеннях порядку, встановленого Законом № $776 / 97$, без відкриття провадження у справі лише «за аналізом» змісту звернення громадянина А. дійшов висновку, що «лист» $є$ відповіддю ПАТ «Укртелеком» і підписаний належною особою.

Верховний Суд роз'яснив, який документ може вважатись офіційним: «Під час встановлення ознак офіційного документа слід керуватися такими критеріями: документ має бути складено, видано чи посвідчено відповідною особою в межах іï компетенції за визначеною законом формою та 3 належними реквізитами; зафіксована в такому документі інформація повинна мати юридично значущий характер: підтверджені чи засвідчені нею конкретні події, явища або факти мають спричиняти чи бути здатними спричинити наслідки правового характеру у вигляді виникнення (реалізаціiі), зміни або припинення певних прав та/або обов'язків» [6].

Підзаконними нормативно-правовими актами, якими встановлено вимоги щодо належної правової процедури складання та форми і змісту офіційних документів, зокрема листів установ та організацій незалежно від форм власності, є Уніфікована система організаційно-розпорядчої документації. Вимоги до оформлювання документів ДСТУ 4163-2003 затверджено наказом Держспоживстандарту України від 7 квітня 2003 року № 55. Правила організації діловодства та архівного зберігання документів у державних органах, органах місцевого самоврядування, в установах і організаціях затверджено наказом Міністерства юстиції України від 18.06.2015 року № 1000/5 (далі - Правила) [7; 8].

Відповідно до пункту 9 розділу I («Загальніположення») Правил визначено, що в межах компетенції установи можуть надсилати листи громадянам [8].

Відповідно до пункту 1 розділу 7 («Підписання управлінських документів») Правил визначено, що посадові особи підписують документи в межах своїх повноважень, визначених у положеннях (статутах) установи, положеннях про структурні підрозділи, посадових інструкціях, розпорядчому 
документі про розподіл обов'язків між керівником та його заступниками тощо. У зазначених документах визначається також порядок підписання документів іншими особами в разі відсутності керівника установи та посадових осіб, які уповноважені їх підписувати [8].

Право підписання документів може надаватися посадовим та іншим особам на підставі довіреності [8].

Відповідно до частини 3 статті 244 Цивільного кодексу України (далі ЦК України) довіреністю є письмовий документ, що видається однією особою іншій особі для представництва перед третіми особами [9].

Відповідно до частини 1 статті 246 Цивільного кодексу України (далі ЦК України) довіреність від імені юридичної особи видається ії органом або іншою особою, уповноваженою на це ії установчими документами [9].

За правовим аналізом Глави 17 ЦК України можливо констатувати, що довіреність від імені юридичної особи має обов'язкові головні реквізити, зокрема: П.І.Б., посада особи, яка надає відповідні повноваження, та особи, що здійснює представництво, конкретні межі наданих такій особі повноважень на вчинення дій/ прийняття рішень, строк дій довіреності [9].

Отже, ПАТ «Укртелеком» може звернутися через представника лише на підставі документу, що посвідчує повноваження такого представника у визначеному законом порядку.

Але всупереч вимогам законодавства до «листа» не додано оригіналу чи відповідно завіреної копії довіреності, за якою особа, яка вказана як представник ПАТ «Укртелеком», має право підпису.

Таким чином, «лист» підписано особою, право якої на вчинення таких дій не підтверджено у встановленому законом порядку, а такий лист складено в порушення належної правової процедури, і він не відповідає формі і змісту офіційного документу, а інформація, викладена в такому листі, не має будь-якого юридичного значення.

Висновки. Інститут Уповноваженого є важливим парламенським правовим механізмом захисту конституційних прав і свобод людини і громадянина в різних сферах діяльності держави. Він, зокрема, спрямований на досудовий захист конституційних прав і свобод людини і громадянина. Досудовий захист має законодавчо визначений спосіб та порядок реалізації, який передбачає системне та комплексне застосування матеріально-правових і процесуальних норм національного законодавства. Вчинення дій, прийняття рішень, одержання відповідних доказів Уповноваженим, зокрема за зверненнями людини і громадянина, мають здійснюватись виключно в порядку, передбаченому законом. Ігнорування цього призведе до вкрай негативних наслідків - зокрема, продовження порушень конституційних прав і свобод людини і громадянина, зниження авторитету та довіри до державної інституції, можливості оскарження дій та рішень Уповноваженого в суді та визнання доказів, одержаних усупереч встановленому законом порядку, недопустимими. 


\section{Література}

1. Конституція України. URL : https:/ / zakon.rada.gov.ua/laws/show/254к/96-вр.

2. Рішення Конституційного Суду України від 8 вересня 2016 року

№ 6-рп/2016. URL : https://zakon.rada.gov.ua/laws/show/v006p710-16.

3. Закон України від 23.12.1997 № 776/97-ВР «Про Уповноваженого Верховної Ради України $з$ прав людини» (із змінами та доповненнями). URL : https:/ / zakon.rada.gov.ua/laws / show /776/97-вр.

4. Закон України від 02.10.1996 № 393/96 - ВР «Про звернення громадян» (із змінами та доповненнями). URL : https:// zakon2.rada.gov.ua/laws/show/393/96-вр.

5. Яковенко Є.О. «Правові аспекти одержання органами державної влади доказів з дотриманням національних конституційних стандартів». Науковий збірник «Приватне та публічне право». 2019. № 1, 33. 40 с.

6. Постанова Верховного Суду від 01.03.2018 по справі № 461/7315/15-к. URL : http:/ / reyestr.court.gov.ua/Review/72641802.

7. Уніфікована система організаційно-розпорядчої документації. Вимоги до оформлювання документів ДСТУ 4163-2003, затверджено наказом Держспоживстандарту України від 7 квітня 2003 року № 55. URL : https:/ / zakon.rada.gov.ua/rada/show/v0055609-03.

8. Правила організації діловодства та архівного зберігання документів у державних органах, органах місцевого самоврядування, в установах і організаціях, затверджено наказом Міністерства юстиції України від 18.06.2015 року № 1000/55. URL : https://zakon.rada.gov.ua/laws/ show / z0736-15.

9. Цивільний кодекс України. URL : https://zakon.rada.gov.ua/laws/show/435-15.

\section{Aнотація}

Яковенко Є. О. Деякі правові аспекти досудового захисту конституційних прав людини і громадянина Уповноваженим Верховної Ради України з прав людини. Стаття.

У публікації автором розглянуто правові аспекти досудового захисту конституційних прав і свобод людини і громадянина під час звернення до Уповноваженого Верховної Ради з прав людини, зокрема його компетенції та порядок розгляду звернень, одержання доказів.

Ключові слова: Уповноважений Верховної Ради з прав людини, звернення людини громадянина, конституційні права і свободи людини і громадянина, порядок, одержання доказів.

\section{Анн о т а ци я}

Яковенко $E$. A. Некоторые правовые аспекты досудебной защиты конституционных прав человека Уполномоченным Верховной Рады Украины по правам человека. Статья.

В публикации автором рассмотрены правовые аспекты досудебной защиты конституционных прав и свобод человека и гражданина при обращении к Уполномоченному Верховной Рады по правам человека, в частности его компетенции и порядок рассмотрения обращений, получения доказательств.

Ключевые слова: Уполномоченный Верховной Рады по правам человека, обращение человека и гражданина, конституционные права и свободы человека и гражданина, порядок, получение доказательств.

\section{S u m m a r y}

Yakovenko Ye. O. Some legal aspects of pre-trial protection of constitutional rights of the Verkhovna Rada of Ukraine on human rights. - Article.

In the publication, the author discusses the legal aspects of the pre-trial protection of constitutional rights and freedoms of a person and citizen when applying to the Commissioner of the Verkhovna Rada for Human Rights, in particular his competence and the procedure for considering appeals and obtaining evidence.

Key words: Verkhovna Rada Commissioner for Human Rights, appeal of man and citizen, constitutional right and freedom of man and citizen, procedure, obtaining evidence. 